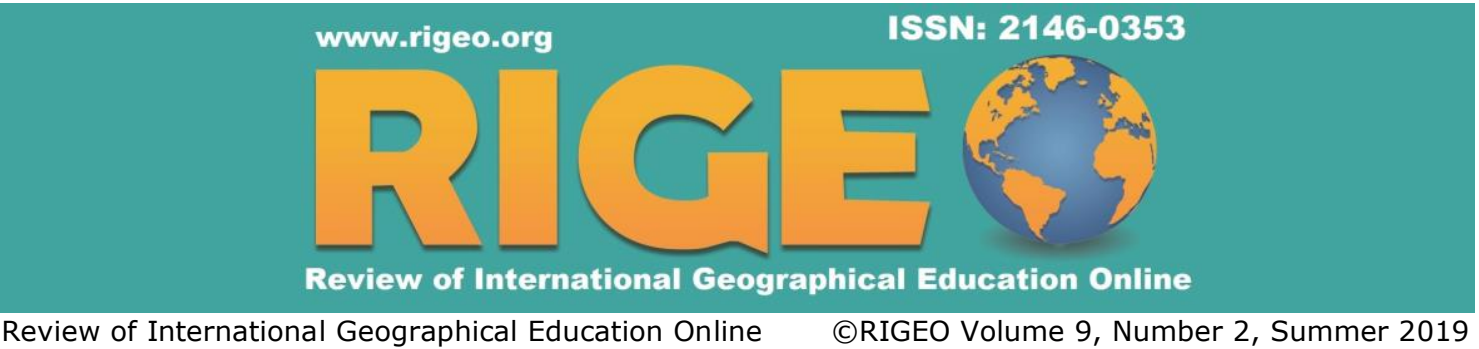

Research Article

Copyright $\odot$ RIGEO 2019

To cite this article: Tomal, N.; Yılar, M.B. (2019). An Evaluation of Social Studies Textbooks in Turkey: A Content Analysis for Curriculum and Content Design. Review of International Geographical Education Online (RIGEO), 9(2), 447-457. Retrieved from http://www.rigeo.org/vol9no2/Number2Summer/RIGEO-V9-N2-9.pdf

DOI: $10.33403 /$ rigeo.579946

Submitted: June 19, 2019

Revised: July 27,2019

Accepted: August 18, 2019

\title{
An Evaluation of Social Studies Textbooks in Turkey: A Content Analysis for Curriculum and Content Design
}

\author{
Necati TOMAL ${ }^{1}$ \\ Ondokuz Mayıs University, Samsun, TURKEY \\ Murat Bayram YILAR ${ }^{2}$ \\ Ondokuz Mayıs University, Samsun, TURKEY
}

\begin{abstract}
The objective of this study is to evaluate the content of social studies textbooks, which are written and taught based upon the social studies curriculum adopted between 1968-2018, in terms of the curriculum and content designs, and some general educational principles. For this purpose, document analysis, one of the qualitative research methodology, was used in this study. Accordingly, 12 social studies textbooks for different levels of class written based upon the social studies curriculum adopted in 1968, are the primary document resources of the research. The curriculum, upon which the textbooks are based, was also used as resource. For data analysis, content analysis technique was used. The results obtained from the study show that the generally-adopted approach to develop the content of social studies textbooks was single-disciplinary approach before 2005; however it was replaced by interdisciplinary approach then, with the impact of changing curriculum. Another study result shows that the content of social studies textbooks was developed based upon the disciplines of history and geography in general, and also citizenship to a limited extent before 2005. However, as it is determined, many other disciplines such as psychology, sociology, economics, science and technology in addition to those specified above, have a major impact on the content of textbooks since this date. Also, the relevant results indicate that the knowledge content was much richer in textbooks before 2005; however, in the current social studies textbooks, the knowledge intensity has decreased as the knowledge variety has increased in time. It has been determined that the social studies textbooks are developed by considering the chronology and from near-to-far principles in general so far.
\end{abstract}

Keywords

Textbook; Curriculum; Social Studies

${ }^{1}$ Corresponding author: Assoc. Prof.; Faculty of Education; Ondokuz Mayıs University, Samsun, Turkey; E-mail: ntomal [at] omu.edu.tr; ORCID: 0000-0002-4365-6582

${ }^{2}$ Assist. Prof.; Faculty of Education; Ondokuz Mayıs University, Samsun, Turkey; E-mail: bayram.yilar [at] omu.edu.tr; ORCID: 0000-0001-5889-3372

(C) Review of International Geographical Education Online

RIGEO 2019

ISSN: 2146-0353

www.rigeo.org 
For better comprehension of the subject, information on the period from the introduction of social studies class into the Turkish elementary and secondary school curricula and the social studies textbooks as a teaching material.

\section{Theoratical Framework}

\section{Development of Social Studies Education in Turkey}

Social studies have been taught as a compulsory course in Turkish elementary schools since 1968, and also in secondary schools since 1975 despite some interruptions time to time (Ambarl, 2010, p. 20).

Developed based upon the relevant curriculum, the textbooks are the most important materials of educational activities provided for students and teachers. These materials help students reach the information and help teachers develop the education process. As with the textbooks of other disciplines, social studies textbooks have been considerably changed in time in parallel with the changes in the curriculum. When reviewing the literature, it has been realized that a good number of studies was carried out on social studies textbooks from past to present. There are many studies that have been carried out especially on social studies textbooks renewed depending on the curriculum change in 2005. It is seen that there are a growing number of studies on the social studies textbooks used in Turkey since 2005 school year, and that the majority of the opinions on the textbooks from the said period has become mostly positive. However, some of these studies highlight issues with the social studies textbooks in terms of content. In this study, the positive and negative aspects of textbooks written both before and after 2005 were evaluated in terms of their contents.

\section{Methodology}

\section{Research Design}

A qualitative approach was adopted, and document analysis, which is a qualitative data collecting technique, was used in this study. Document analysis is a method that consists of some systematic steps intended for reviewing or evaluating of printed and electronic documents (Bowen, 2009, p. 27).

The document sources of the study consist of 12 social studies textbooks used on the 4th, 5th, 6th and 7th grade levels between 1968 and 2018. To be able to accurately evaluate the content of social studies textbooks from 1968 to the present day, the textbooks from different grade levels and with contents specifically based on the curricula that were effective in different periods.

The social studies textbooks taught between 1968 and 2018 were used as the main data source in content evaluation for the study. The textbooks subject to document analysis in this study, are given in the Table 1: 
Table 1

Data on Textbooks Used as Data Resource in the Study

\begin{tabular}{|c|c|c|c|}
\hline Writer name & Year & $\begin{array}{l}\text { Textbook } \\
\text { name }\end{array}$ & Publisher \\
\hline Rakım Çalapala & $1978 \mathrm{a}$ & $\begin{array}{l}\text { Social Studies } \\
\text { (Elementary:4) }\end{array}$ & $\begin{array}{l}\text { İnk1lap and Aka } \\
\text { Publishing } \\
\text { Houses }\end{array}$ \\
\hline Rakım Çalapala & $1978 b$ & $\begin{array}{l}\text { Social Studies } \\
\text { (Elementary:5) }\end{array}$ & $\begin{array}{l}\text { İnk1lap and Aka } \\
\text { Publishing } \\
\text { Houses }\end{array}$ \\
\hline $\begin{array}{l}\text { Niyazi Akşit, Ferruh Sanır } \\
\text { and Tarı Asal }\end{array}$ & 1979 & $\begin{array}{l}\text { Social Studie } \\
\text { for Secondary } \\
\text { Schools } 2\end{array}$ & $\begin{array}{l}\text { National } \\
\text { Education Press }\end{array}$ \\
\hline $\begin{array}{l}\text { Güler Şenünver, Ezdihar } \\
\text { Karabulut, H. Samim } \\
\text { Kesim, Rıfat Turgut, } \\
\text { Nesibe Ercan, Mustafa } \\
\text { Küçükbaycan, Hasan } \\
\text { Huslu and Aliye Akiye }\end{array}$ & 1999 & $\begin{array}{l}\text { Elementary } \\
\text { School Social } \\
\text { Studies } 7\end{array}$ & $\begin{array}{l}\text { National } \\
\text { Education Press }\end{array}$ \\
\hline $\begin{array}{l}\text { Güler Şenünver, Ezdihar } \\
\text { Karabulut, H. Samim } \\
\text { Kesim, Rıfat Turgut, } \\
\text { Nesibe Ercan, Mustafa } \\
\text { Küçükbaycan, Hasan } \\
\text { Huslu and Aliye Akiye }\end{array}$ & 2001 & $\begin{array}{l}\text { Elementary } \\
\text { School Social } \\
\text { Studies } 7\end{array}$ & $\begin{array}{l}\text { National } \\
\text { Education Press }\end{array}$ \\
\hline $\begin{array}{l}\text { Demet Karagöz, Meltem } \\
\text { Tekerek, Niyazi Kaya, } \\
\text { Hikmet Azer, Melek Derya } \\
\text { Alıç, Bekir Yılbat, Miyase } \\
\text { Koyuncu, Kadir Ulusoy }\end{array}$ & 2008 & $\begin{array}{l}\text { Elementary } \\
\text { Social Studies } \\
5\end{array}$ & $\begin{array}{l}\text { Ministry of } \\
\text { National } \\
\text { Education } \\
\text { Publications }\end{array}$ \\
\hline $\begin{array}{l}\text { Emine Genç, Mecit Mümin } \\
\text { Polat, Samettin Başol, } \\
\text { Niyazi Kaya, Hikmet Azer, } \\
\text { Sevil Gökçe, Miyase } \\
\text { Koyuncu, Abdul Celil } \\
\text { Gök, Abdullah Yıldız, } \\
\text { Dilek Yılmaz, Âdem } \\
\text { Özcan }\end{array}$ & 2008 & $\begin{array}{l}\text { Elementary } \\
\text { Social Studies } \\
6\end{array}$ & $\begin{array}{l}\text { Ministry of } \\
\text { National } \\
\text { Education } \\
\text { Publications }\end{array}$ \\
\hline $\begin{array}{l}\text { Murat Gürkan Gülcan, } \\
\text { Özen Bayram, Zafer Kılıç, } \\
\text { Fatih. M. Karakaya, Aliye } \\
\text { Midilli }\end{array}$ & 2010 & $\begin{array}{l}\text { Elementary } \\
\text { 5th Grade } \\
\text { Social Studies } \\
\text { Textbook }\end{array}$ & $\begin{array}{l}\text { Koza Publishing } \\
\text { \& Distribution }\end{array}$ \\
\hline Ömer Faruk Evirgen, & 2017 & Social Studies & Ministry of \\
\hline
\end{tabular}




\begin{tabular}{llll}
\hline $\begin{array}{l}\text { Julide Özkan, Suna } \\
\text { Öztürk, Zuhal Özdural }\end{array}$ & Textbook 5 & $\begin{array}{l}\text { National } \\
\text { Education } \\
\text { Publications }\end{array}$ \\
\hline Erhan Şahin & 2018 & $\begin{array}{l}\text { Social Studies } \\
\text { Textbook 5 }\end{array}$ & $\begin{array}{l}\text { Anadolu } \\
\text { Yayincilik }\end{array}$ \\
\hline Faruk Gökalp Y1lmaz, & 2018 & Social Studies & Ministry of \\
Hasan Bayraktar, Mustafa & & Textbook 6 & National \\
Kemal Özden, Murat & & & Education \\
Akpınar, Ömer Evin & & & Publications \\
\hline $\begin{array}{l}\text { Gökhan Gültekin, Murat } \\
\text { Akpınar, Mustafa Nohutcu, }\end{array}$ & 2018 & Social Studies & Ministry of \\
Pinar Özerdoğan, Seher & & Textbook 7 & National \\
Aygün & & & Education \\
\hline
\end{tabular}

As part of the study, the general evaluation of the contents of social studies textbooks referred to the textbooks given in Table 1, as well as various publications examining social studies education curricula and textbooks of 1968, 1998, 2005 and 2018 in terms of content (Nas, 2000; Demirel, 2010; 2012; Baykara, 2012).

Content analysis technique was utilized in the analysis of the data obtained from the study. Content analysis, which is a widely used qualitative research method, is one of the research methods in which text data is analyzed based on the content or contextual meaning of the text (Hsieh \& Shannon, 2005, p. 1277-1278). The process of content analysis involves bringing together similar data on the basis of certain concepts and themes and interpreting them in a way that is comprehensible for the reader (Y1ldirim and Şimşek, 2013, p. 259). This study only covered the themes out of the code, category and theme trio that is frequently created in content analysis, and the contents of social studies textbooks were evaluated under these themes according to their prominent features, as well as common and distinct points. In order to improve the reliability of the study, the obtained data were discussed periodically with the domain experts, and the documents were revised where differences had been detected.

\section{Findings}

The content analysis carried out for the study revealed significant changes in the content of the textbooks throughout the period spanning the years when the social studies course was introduced to the primary and secondary school curricula up to the present day. This section aims to analyze said changes in the content of social studies textbooks under 2 main headings, which are curriculum development and content design theme and general teaching principles theme.

\section{Evaluation of Content in terms of Curriculum Development and Content Designs}

According to the study, social studies curriculum comprising of subjects that are in relation to each other such as history, geography, sociology, etc. is enough for this curriculum to be considered a curriculum with extensive design. There is no need to 
blend together information from different fields in a learning domain. After all, as agreed by some researchers, extensive design should be considered alongside interdisciplinary design, and therefore, content from various areas should be integrated in a textbook based on extensive design. Otherwise, the textbooks used prior to 2005 , which usually included information on each field under individual units except for those regarding citizenship knowledge, or in other words, which were based on the sense of single discipline where history, geography and citizenship knowledge textbooks are combined into a singe textbook, can be considered extensive design textbooks only in name. Rather than such content systematic, it may be more convenient to have separate courses such as history and geography that constitute the social studies course. The current social studies textbooks, on the other hand, seek to combine information from different fields in a learning domain. In other words, existing social studies textbooks can be considered in the context of extensive design both in name and practice, based on interdisciplinary design.

The previous chapters of the study have mentioned how current and previous social studies textbooks emphasize general teaching principles such as from near-to-far and chronology. Based on these explanations, it can be said that linear content approach has been utilized in social studies curriculum and textbooks. Also, with the increase in detail, the repetition-oriented spiral approach has been utilized in content creation for social studies textbooks from past to date.

\section{Evaluation of Content in Terms of General Teaching Principles}

Evaluation of content in terms of integrity principle. As stated in the introduction part of the study, social studies was introduced as a course for the first time in primary schools in 1968 and in secondary schools in 1975. When social studies was introduced as a course in primary schools in 1968, the textbook had not been prepared yet, and this continued until 1975. One of the supplementary textbooks used in the early 1970s until the textbooks were prepared was the social studies textbooks by Çalapala (Alaca, 2017, p. 762). As can be seen in these examples on the content systematic of the social studies textbooks from previous years, it is thought that it may prove confusing for students if subjects that are continuations of one another are interrupted for other subjects and resumed later. Therefore, based on these explanations, one can talk about an issue of content complexity or a disorganized content systematic here. Despite this unfavorable aspect, the primary concern behind the fact that history and geographysubjects are featured together and taught alternately or a unit is entirely comprised of geographysubjects and the next one is comprised of historysubjects in social studies textbooks might have been to avoid boredom among students.

Each learning domain is internally coherent in terms of content; it does not have significant direct relation with the preceding or following learning domains. That is to say, the social studies textbooks that are currently being taught are largely comprised of independent learning domains. As a matter of fact, these textbooks were prepared with the intention of achieving internal coherence within each learning domain. 
Evaluating the content in terms of chronology and from near-to-far principles. An examination of the order of history and geography subjects taught in successive grades is necessary to be able to make an evaluation about whether the previous and current social studies textbooks take the chronology principle, which is crucial in the teaching of history subjects, or from near-to-far principle, which is required for geography teaching, into consideration. In this context, in addition to the 1978 edition of the 5th grade textbook, for which have provided examples above about its content, the 4th grade textbook was also analyzed in terms of chronology and from near-to-far principles.

The contents of the social studies textbooks published prior to 2005 were prepared according to the order from the past to the present day, thus they clearly take chronology into consideration. The order of history subjects in the current social studies textbooks and ones prepared according to the 2005 curriculum is largely the same as that of the previous textbooks. The only difference with the previous social studies textbooks is that, in the social studies textbooks prepared after 2005, the subject of ancient civilizations precedes the first Turkish states (Genç, Polat, Başol, S., et al., 2008).

In the 1978 edition of 4th and 5th grade social studies textbook, geography subjects are listed as follows: The order of the 4th grade textbook follows the subjects 'our province' (the province where the student resides is thoroughly introduced), 'Turkey's geographic regions', 'the geography of Turkey', respectively, while the order of the 5th grade geography follows the subjects 'latitude and longitude', 'the position of Turkey', 'Turkey's neighbors', 'the Earth's movements', 'the formation of the seasons and daynight cycle', 'major countries of the world'. (Çalapala, 1978a). Therefore, it can be said that, throughout the period until 1997, the contents of social studies textbooks were prepared based on from near-to-far principle. As with all other textbooks published before 2005, the 1997 edition of 4th grade social studies textbook likewise appears to emphasize the introduction of all aspects of the province where the student resides (Nas, 2000 , p. 502-503). However, when it comes to other geography subjects, no connection is established between each subject and the immediate environment unlike the social studies textbooks of today. For example; the 2001 edition of the 6th grade textbook only focuses on Turkey in general on the subject of 'agriculture in Turkey', while failing to draw attention to the agricultural activities in the region where the student resides (Şenünver et al., 2001, p. 117). The current social studies textbooks, on the other hand, attempts to establish a relation between each topic and the immediate environment through various activities. For example; the 'let's research and share' activity at the end of the geographical formations subject in the 'people, places and environments' learning domain in the 2018 edition of the 5th grade social studies textbook asks the student to do a research on the geographical formations in and around where the student lives (Şahin, 2018, p. 70). Such activities, which help students to become more familiar with their immediate environment, can be found in many parts of the social studies textbooks of today. 
Evaluation of information density and variety in the content in terms of the student-centeredness principle. The content of the textbooks has varied considerably throughout time in terms of information density and diversity. An examination of the 1978 edition 5th grade social studies textbook by Çalapala with regard to information density reveals that the subjects related to geography of countries are highly dense in terms of information.

In pre-2005 text books, the content is mostly comprised of the subjects of history and geography, and the subject of citizenship to a certain degree. In the social studies textbooks prepared after 2005, on the other hand, there has been an increase in the content variety, while information on various fields such as science and technology, economics, sociology, psychology have been featured in textbooks along with history, geography and citizenship (Karagöz, et al., 2008; Genç et al., 2008; Gülcan et al., 2010; Şahin, 2018).

Evaluation of content in terms of from-familiar-to-unfamiliar principle. Although this principle has generally been taken into consideration while preparing content for social studies textbooks both in the past and today, there are also some rare instances where it is disregarded in certain textbooks and subjects. For example; in the current 5th grade social studies textbook, there is a table showing the dates throughout which the Anatolian and Mesopotamian civilizations appeared on and disappeared from the stage of history, and said table also features the terms 'before the common era' and 'common era' (Şahin, 2018, p. 35). Table 2 attempts to summarize the evaluations on the content of both previous and current social studies textbooks based on general teaching principles.

Table 2

Comparison of the contents of social studies textbooks used before and after 2005

\begin{tabular}{ll}
\hline \multicolumn{1}{c}{ Textbooks Published before 2005 } & \multicolumn{1}{c}{ Textbooks Published after 2005 } \\
\hline $\begin{array}{l}\text { 1. The content largely consists of } \\
\text { history and geography, It also includes }\end{array}$ & $\begin{array}{l}\text { 1. Content headlines become greatly } \\
\text { a certain degree of citizenship subjects. Subjects on citizenship, economy, } \\
\text { science and technology are given greater } \\
\text { emphasis. }\end{array}$ \\
\hline $\begin{array}{l}\text { 2. Detailed information is provided on } \\
\text { a large number of countries. }\end{array}$ & $\begin{array}{l}\text { 2. Brief information is provided on a } \\
\text { small number of countries within a } \\
\text { specific context. }\end{array}$ \\
\hline $\begin{array}{l}\text { 3. Information about the geographical } \\
\text { features of Turkey is featured on a } \\
\text { regional basis. }\end{array}$ & $\begin{array}{l}\text { features of Turkey is featured within the } \\
\text { context of each individual geographic } \\
\text { feature rather than on a regional basis. }\end{array}$ \\
\hline $\begin{array}{l}\text { 4. The content of the textbook follows } \\
\text { the order of one history unit and one }\end{array}$ & $\begin{array}{l}\text { 4. Units are featured independently of } \\
\text { geography unit, or either history or }\end{array}$ \\
geography units until the end of a main \\
subject.
\end{tabular}


5. Textbooks for the low grade levels mainly focuses individually on the subjects about the immediate environment.

6. Except a number of subjects, history subjects are mostly featured in chronological order. However, in some social studies text books, the fact that history units on the same subject are interrupted by geography units may prove problematic with regard to chronology.

7. The same subject is usually featured in both elementary and secondary school social studies textbooks, with differences in the level of detail.

8. Today, a large number of subjects featured in secondary school textbooks are featured in the lower grade textbooks as well.
5. A connection is mainly established between each subject and the immediate environment in all grade levels.

5. Events given follow chronological order. All subjects on history domain are covered in a single unit. They are not interrupted by subjects on other sciences.

7. The subjects featured in the textbooks are usually featured in educational books of a certain level (E.g. the Ottoman Empire subject is only covered in secondary school textbooks).

8. Subjects are featured in the textbooks of certain grades based on the developmental characteristics of students.

\section{Result and Recommendations}

The date 2005 is vital for making an evaluation of the social studies textbooks from past to present. The content of the social studies textbooks published before and after this date differs substantially in many aspects. This section aims to offer a brief summary about the extensive evaluations on said differences in the findings sections.

Since social studies curricula and textbooks up to 2005 features a separate unit for subjects from each discipline except subjects on citizenship, they can be considered in the context of extensive design in name and single-discipline design in practice. The current social studies textbooks, on the other hand, can be considered in the context of extensive or interdisciplinary design both in name and practice (Barth, 1991; Güngördü, 2002; Semenderoğlu and Gülersoy, 2005; Sunal \& Haas, 2005; Doğanay, 2008; Y1lar and Tomal, 2018). In the current social studies textbooks, blending together the information on distinct fields has not been difficult in the context of multidisciplinary approach for the geography-intensive learning domains due to the interdisciplinary nature of this scientific field. There has been an attempt to exercise an interdisciplinary approach to some extent with the inclusion of subjects such as the Turkish cultural wealth in the history-intensive learning domain of culture and heritage. As for the learning domains regarding the subjects such as citizenship, science, technology and society, blending information is easy as their subject matter is associated with numerous fields. 
It can be maintained that the content design for both previous and current social studies textbook is based on the spiral curriculum approach, since same units are occasionally taught in different grades again (Doğanay, 2008; Y1lar and Tomal, 2018; Zarillo, 2016). Likewise, the fact that general teaching principles such as from-near-tofar, chronology, and from-familiar-to-unfamiliar are taken into consideration in many parts of these textbooks shows how linear approach design is also influential in the content design. However, featuring the same geography subjects on current social studies textbooks for different grades, or for the same grade in different learning domains, without any substantial change in detail has led to redundant repetitions. This issue actually arises from misapplication of the spiral approach.

Prior to 2005, social studies textbooks comprising largely of history, geography, and to a lesser extent, citizenship subjects (MEB, 1997; 1998) were more prominent. But, there has been a particular increase in the significance of citizenship field (MEB, 2005; 2018). To date, new headings have been added to the social studies textbooks, while most of the existing headings also preserved their place in the current social studies textbooks. For example, the history subjects featured in the curriculum of 1998 remain largely the same as current history subjects. Nevertheless, less and less time has been allocated for these subjects with the addition of new subjects in the textbooks. Since geography subjects or the subjects related to geography extend to numerous learning domains in the current textbook, the problem with time in the teaching of history subjects is not encountered in the subjects of geography discipline. But, since the subjects related to the science of geography extend to numerous learning domains, this occasionally leads to redundant repetitions and interruptions in the coherence of the subject. Particularly the fact that the geography subjects extend to the numerous learning areas gives rise to a complexity in the content systematic.

It is safe to say that pre-2005 social study text books are very intensive in terms of information. The textbooks prepared in accordance with the social studies curricula preceding the curriculum of 1998 in particular are clearly far more intensive in terms of information. In the textbooks published prior to this date, geography of countries is the primary subject with the highest information density. Current social studies textbooks, on the other hand, features far less information on various countries around the world than it should. A few sentences and concise information on the geographical features of these countries can be included in the textbooks.

A shift toward higher grades in the teaching of many subjects included in social studies teaching from past to present is generally in line with the student-centeredness principle. However, the matter of which subject will be taught in which grade and to what extent while taking students' developmental characteristics into consideration is a difficult and controversial issue. And such an issue requires more specialized and extensive studies. 


\section{References}

Akşit, N., Sanır, F., \& Asal, T. (1979). Ortaokullar için sosyal bilgiler 2. Ankara: Milli Eğitim.

Alaca, E. (2017). An evaluation of social studies course books. Education and Society in the $21^{\text {st }}$ Century, 6(18), 759-785.

Ambarl1, A. (2010). Elemantary education social studies curriculum in Turkey modifications, corrections, updating (Unpublished master's thesis). Selçuk University Institute of Educational Sciences, Konya.

Barth, J. (1991). Elementary and junior high/middle school social studies curriculum. lanham, Md.: University Press of America.

Baykara, K. (2012). İçeriğin ve eğitim durumlarının düzenlenmesi yaklaşımı. H. Şeker (Ed.), Eğitimde program geliştirme içinde (s. 168-172), Ankara: Anı.

Bowen, G. A. (2009). Document analysis as a qualitative research method. Qualitative Research Journal, 9(2), 27-40.

Çalapala, R. (1978a). Sosyal bilgiler (ilkokul: 4). İstanbul: İnkılap ve Aka.

Çalapala, R. (1978b). Sosyal bilgiler (ilkokul: 5). İstanbul: İnkılap ve Aka.

Demirel, Ö. (2010). Ĕgitimde program geliştirme. Ankara: Pegem Akademi.

Doğanay, A. (2008). Çağdaş sosyal bilgiler anlayışı 1şı̆̆ında yeni sosyal bilgiler programının değerlendirilmesi. Journal of Çukurova University Institute of Social Sciences, 17(2), 7796.

Evirgen, Ö. F., Özkan, J., Öztürk, S., \& Özdural, Z. (2017). Sosyal bilgiler 5. Sinıf kitabl. Ankara: MEB Yayınları.

Genç, E., Polat, M. M., \& Başol, S. (2008). Sosyal bilgiler 6. Ankara: Milli Eğitim Bakanlığı.

Gülcan, M.G., Bayram, Ö., Kılıç, Z., Karakaya, F.M. \& Midilli, A. (2010). Sosyal bilgiler 5. Ankara: Koza Yayın.

Gültekin, G., Akpınar, M., Nohutçu, M., Özerdoğan, P., \& Aygün, S. (2018). Sosyal bilgiler 7. Sınıf kitabı. Ankara: Millî Eğitim Bakanlığı.

Güngördü, E. (2002). Illköğretimde hayat bilgisi ve sosyal bilgiler öğretimi. Ankara: Nobel.

Hsieh, H.F., \& Shannon, S. E. (2005). Three approaches to qualitative content analysis. Qualitative Health Research, 15(9), 1277-1288. doi:10.1177/1049732305276687

Karagöz, D., Tekerek, M., Kaya, N., Azer, H., Alıç, M.D., Yılbat, B., Koyuncu, M. \& Ulusoy, K. (2008). Sosyal bilgiler 5. Ankara: Milli Eğitim Bakanlığı.

MEB. (1997). İlkögretim okulu programı. Ankara.

MEB. (1998). İlköğretim okulu sosyal bilgiler program1. Tebliğler Dergisi, 2487, 531-568.

MEB. (2005). İlköğretim sosyal bilgiler dersi 6-7 ögretim programı kılavuzu. Ankara.

MEB. (2018). Sosyal bilgiler dersi ögretim programı. (Illkokul ve ortaokul 4, 5, 6 ve 7. sinıflar). Ankara.

Nas, R. (2000). Hayat bilgisi ve sosyal bilgiler ögretimi. Bursa: Ezgi.

Şahin, E. (2018). Sosyal bilgiler 5. Ankara: Anadolu. 
Semenderoğlu, A., \& Gülersoy, A. E. (2005). Eski ve yeni 4-5. Sinıf sosyal bilgiler öğretim programlarının değerlendirilmesi. Dokuz Eylül University Buca Faculty of Education Journal, 18, 141-152.

Şenünver, G., Karabulut, E., Kesim, H., Turgut, R., Ercan, N., Küçükbaycan, M., Huslu, H., \& Akiye, A. (1999). Sosyal bilgiler 7. İstanbul: Milli Eğitim.

Şenünver, G., Karabulut, E., Kesim, H., Turgut, R., Ercan, N., Küçükbaycan, M., Huslu, H., \& Akiye, A. (2001). Sosyal bilgiler 6. İstanbul: Milli Eğitim.

Sunal, C.S., \& Haas, M.E. (2005). Social studies for the elementary and middle grades a constructivist approach. USA: Pearson Education.

Yılar, M.B., \& Tomal, N. (2018). Sosyal bilgiler dersi ve yenilenen ders öğretim programı. A. Uzunöz ve V. Aktepe (Ed.). Özel ögretim yöntemleri-cilt-2 içinde (s. 1-42). Ankara: Pegem Akademi.

Yıldırım, A., \& Şimşek, H. (2013). Sosyal bilimlerde nitel araştırma yöntemleri. (9. Baskı), Ankara: Seçkin.

Yılmaz, F., Bayraktar, H., Özden, M., Akpınar, M., \& Evin, Ö. (2018). Sosyal bilgiler 6. Ankara: Milli Eğitim Bakanlığı.

Zarillo, J.J. (2016). Sosyal bilgiler ögrretimi-ilkeler ve uygulamalar. B. Tay ve S. B. Demir (Çev.). Ankara: Anı.

\section{Biographical Statements}

Necati TOMAL is an Associate Professor at Ondokuz May1s University, Faculty of Education Department of Social Studies Education. His main research interests include curricula, textbooks, and teaching methods and styles.

Murat Bayram YILAR is a Assistant Professor at Ondokuz Mayis University, Faculty of Education, Department of Social Studies Education. His research interests include social studies education and cooperative learning. 